\title{
Reversible exposure of hydrophobic residues on albumin as a novel strategy for formulation of nanodelivery vehicles for taxanes
}

This article was published in the following Dove Press journal:

International Journal of Nanomedicine

10 June 2011

Number of times this article has been viewed

\section{AG Garro' \\ DM Beltramo 1,2,3 \\ RV Alasino' \\ $\checkmark$ Leonhard ${ }^{1,2}$ \\ $\checkmark$ Heredia' \\ ID Biancol,2,4}

'Center of Excellence in Products and Processes of Córdoba; ${ }^{2}$ National Research Council of Argentina (CONICET); ${ }^{3}$ School of Chemistry, Catholic University of Córdoba; ${ }^{4}$ Department of Exact, Physical and Natural Sciences, National University of La Rioja, Argentina
Correspondence: ID Bianco

Centro de Excelencia en Productos

y Procesos de Córdoba, Ministerio de Ciencia y Tecnología de Córdoba, Pabellón, CP 5164, Santa María de Punilla, Córdoba, Argentina

Tel +54354|48 965I/53 ext I43

Fax +54354|48 8|8|

Email ibianco@ceprocor.uncor.edu
Background: We report herein a novel strategy for the preparation of protein-based nanodelivery vehicles for hydrophobic active pharmaceutical ingredients.

Methods: The procedure consisted of three steps, ie, exposure of hydrophobic residues of a protein to a $\mathrm{pH}$-induced partial unfolding: interaction between hydrophobic residues on the protein and the hydrophobic active pharmaceutical ingredient, and a final step where the structure of the protein was reversed to a native-like state by returning to neutral $\mathrm{pH}$. As proof of concept, the interaction of paclitaxel with partially unfolded states of human serum albumin was evaluated as a potential method for the preparation of water-soluble complexes of the taxane with albumin.

Results: We found that paclitaxel readily binds to $\mathrm{pH}$-induced partially unfolded albumin, leading to the formation of optically clear water-soluble complexes. The complexes thus formed were more stable in solution when the albumin native state was at least partially restored by neutralization of the solution to a $\mathrm{pH}$ around 7. It was also observed that the hydrodynamic radius of human serum albumin was only slightly increased after the cycle of $\mathrm{pH}$ changes, remaining in a monomeric state with a size according to paclitaxel binding. Furthermore, paclitaxel binding did not affect the overall exposure of charged groups of human serum albumin, as evaluated by its interaction with an ionic exchange resin.

Conclusion: The in vitro biological activity of the complexes formed was qualitatively equivalent to that of a Cremophor ${ }^{\circledR}$-based formulation.

Keywords: human serum albumin, paclitaxel, unfolded states, solubility

\section{Introduction}

Paclitaxel (Taxol ${ }^{\circledR}$, Bristrol-Myers Squibb, New York) is a very potent anticancer agent currently approved as first-line treatment for advanced carcinoma of the ovary, adjuvant treatment of breast carcinoma and nonsmall cell lung cancer, and as a second-line treatment for Kaposi's sarcoma related to acquired immunodeficiency syndrome. ${ }^{1,2}$ Because of its extremely poor aqueous solubility, paclitaxel has been formulated in ethanol and polyethoxylated castor oil (Cremophor $\mathrm{EL}^{\circledR}$ ), a vehicle that has been associated with bronchospasm, hypotension, and various hypersensitivity reactions, in particular after rapid administration or 10 minutes after initiating drug infusion. ${ }^{3,4}$ Premedication with corticosteroids and antihistamines is mandatory to reduce the incidence of serious hypersensitivity reactions. However, milder reactions still occur in 5\%-30\% of treated patients. ${ }^{5}$ To avoid the toxicities associated with the cosolvents required for taxane administration, and also to improve the solubility of paclitaxel, a number of alternative formulation strategies have been investigated. ${ }^{6-8}$ In this context, polyethylene glycol 
was evaluated as a biocompatible polymer which improves water solubility of paclitaxel. However, the polyethylene glycol-paclitaxel complex thus formed showed a decrease in antitumor activity. ${ }^{3}$ Other polymers, such as hyaluronic acid, polyglutamic acid, and nucleic acids, have been evaluated as carriers to improve paclitaxel solubility. Although these complexes had a highly stable composition, the biological activity of the pharmaceutical principal was slow. ${ }^{9,10}$

Proteins have been used as carriers for hydrophobic drugs, especially human albumin. ${ }^{11-14}$ In this context, Desai et al described a composition for in vivo delivery of water-insoluble drugs, such as paclitaxel. ${ }^{11,15}$ In their report, paclitaxel was incorporated in a polymeric shell of albumin with a size no bigger than $10 \mu \mathrm{m}$, which was substantially crosslinked through disulfide bonds induced in the protein by sonication. Desai et al then described a new formulation to deliver paclitaxel. ${ }^{16}$ In this case, the agent was delivered in the form of suspended particles coated with a stabilizing protein. The complex of protein with drug is subjected to high shear, in the absence of conventional surfactants or any polymeric core, a procedure that yielded amorphous nanoparticles with a diameter of less than $200 \mathrm{~nm}$. These results were the basis for the development of Abraxane ${ }^{\circledR}$, a formulation approved by the US Food and Drug Administration for the treatment of metastatic breast cancer. However, the formulation developed has very limited stability upon reconstitution in saline solution (a maximum of 8 hours refrigerated at $2-8^{\circ} \mathrm{C}$ ) and requires the use of a high-pressure homogenizer for its production.

The binding of paclitaxel to human serum albumin (HSA) has been studied using various methodologies. ${ }^{17-19}$ Most of these studies describe the interaction under physiological conditions and are primarily concerned with the determination of binding constants. ${ }^{20-22}$ Nevertheless, comparison of the reported data shows significant differences in affinity constant values, because the experimental conditions for carrying out binding experiments were indeed different.

Another important issue is that most of the formulations developed require the use of a percentage of organic solvent in order to deal with the very low solubility of paclitaxel in aqueous solution. The use of different organic solvents to prepare paclitaxel solutions indeed modifies the interaction process because the nature of paclitaxel binding to HSA is mainly hydrophobic. Because unfolding exposes the hydrophobic residues of proteins, we hypothesized that partially unfolded states of HSA could interact with paclitaxel, leading to formation of water-soluble noncovalent complexes. The results reported here show that reversible acid-induced or alkali-induced denatured forms of albumin interact with paclitaxel, forming complexes that remain associated after protein renaturation, allowing paclitaxel delivery in aqueous media.

\section{Materials and methods}

Paclitaxel was obtained from Yunnan Smandbet Co Ltd (Kunming, China). Stock solutions of paclitaxel were prepared by dissolving the drug in either ethanol or dimethylsulfoxide in a final concentration of $11.1 \mathrm{mg} / \mathrm{mL}$. Further dilutions in organic solvent were prepared as necessary when assaying for different ratios and concentrations.

HSA $20 \%(\mathrm{w} / \mathrm{v})$ with sodium caprylate $(0.04 \mathrm{M})$ and $\mathrm{N}$-acetyl tryptophan $(0.04 \mathrm{M})$ as stabilizers was obtained from the Laboratorio de Hemoderivados, National University of Córdoba, Argentina. To remove the excipients, albumin was dialyzed against distilled water or saline solution, and diluted with distilled nonpyrogenic water to the final concentration used in each assay. Defatted albumin was prepared by adsorption of fatty acids onto charcoal as previously described. ${ }^{23}$ Sodium dodecyl sulfate and urea were from Sigma Chemical Co (St Louis, MO). All other chemicals used were of analytical grade.

\section{Turbidimetry}

Optical density at a wavelength of $600 \mathrm{~nm}$ was used as a measure of the optical clarity of the samples.

\section{Determination of HSA concentration}

Protein concentration was determined using a Coomassie Brilliant blue assay or by direct absorbance at $280 \mathrm{~nm}$, as previously described. ${ }^{24}$

\section{Determination of paclitaxel concentration}

Paclitaxel concentration was measured on a Curosil B $\mathrm{C}_{18}$ column $(250 \times 3.20 \mathrm{~mm}$ ID, particle size $5 \mu \mathrm{m})$ and a Curosil $\mathrm{B} \mathrm{C}_{18}$ guard column $(30 \times 4.60 \mathrm{~mm}$ ID, particle size $5 \mu \mathrm{m})$ supplied by Phenomenex (Torrance, CA). The mobile phase was $60 \%(\mathrm{v} / \mathrm{v})$ acetonitrile and $40 \%(\mathrm{v} / \mathrm{v})$ biodistilled water. Flow rate was $0.7 \mathrm{~mL} / \mathrm{min}$ and the eluent was monitored at $227 \mathrm{~nm}$. Chromatography was performed at ambient temperature $\left(20 \pm 2^{\circ} \mathrm{C}\right)$.

\section{Protein chromatography}

Reaction mixtures and controls were chromatographed on an Äkta Explorer 100 system (GE Healthcare, Barrington, IL) fitted with a Superdex 200 or Mono Q column previously equilibrated with $50 \mathrm{mM}$ phosphate buffer $(\mathrm{pH}$ 7.0) and $100 \mathrm{mM} \mathrm{NaCl}$ (phosphate-buffered saline). The elution 
profile was followed using an ultraviolet detector at $280 \mathrm{~nm}$, and the total protein levels were quantified using a Coomassie brilliant blue assay. ${ }^{24}$ Molecular weight markers in concentrations of $3 \mathrm{mg} / \mathrm{mL}$ were run similarly, and fractions analyzed for protein content using the Coomassie brilliant blue assay. HSA was eluted from the anion exchange resin with $50 \mathrm{mM}$ sodium phosphate $\mathrm{pH} 7.0,0.5 \mathrm{M} \mathrm{NaCl}$.

\section{Water-soluble paclitaxel noncovalently bound to albumin}

Paclitaxel was solubilized in an organic solvent, such as ethanol or dimethylsulfoxide, and the solutions were then centrifuged to remove any potential particles. The solutions were slowly added under gentle agitation to the solution of HSA previously adjusted to the different conditions to be tested. After 1 hour of stabilization at the selected experimental conditions (temperature, $\mathrm{pH}$, and ionic strength), the $\mathrm{pH}$ was slowly adjusted to $7.0 \pm 0.2$ with $1 \mathrm{M}$ Tris- $\mathrm{HCl} \mathrm{pH} 7.0$, if necessary, and the paclitaxel precipitated was removed by centrifugation $(14,000 \times \mathrm{g}, 10$ minutes $)$ at a series of time intervals. Finally, an aliquot of supernatant $(300 \mu \mathrm{L})$ was filtered through $0.2 \mu \mathrm{m}$ and the concentration of paclitaxel in solution (bound and unbound to HSA) was determined by reverse-phase high-pressure liquid chromatography. The amount of insoluble paclitaxel was determined from the precipitates by reverse-phase high-pressure liquid chromatography after its solubilization in ethanol.

\section{Human larynx epithelioma cell culture conditions}

Human larynx epithelioma cells (ATCC CCL-23) were propagated in minimum essential medium supplemented with 10\% irradiated fetal bovine serum (Natocor, Córdoba, Argentina), 100,000 IU/L penicillin (Life Technologies, Rockville, MD), and $2 \mathrm{mM}$ L-glutamine (Sigma). Cell monolayers were incubated in the above medium in the presence or absence of different concentrations of paclitaxel: HSA or paclitaxel in Cremophor (control) over 24 hours. Cell viability was assayed by trypan blue exclusion. Cell monolayers were photographed without any staining in an Axiovert $135 \mathrm{M}$ Carl-Zeiss microscope at $50 \times($ Oberkochen, Germany).

\section{Results and discussion Solubilization of paclitaxel by interaction with reversibly denatured HSA}

It is known that HSA undergoes reversible conformational isomerization with changes in $\mathrm{pH}$ of the solution containing the protein. ${ }^{25,26}$ At neutral $\mathrm{pH}$, HSA assumes the normal form, which abruptly changes to a highly charged fast migrating form at $\mathrm{pH}$ values lower than 4.3 because this form moves "fast" on gel electrophoresis. In this condition, albumin is in a compact partially denaturated state, with a significant amount of secondary structure but a largely disordered tertiary structure. ${ }^{27}$ Upon further reduction in $\mathrm{pH}$ to lower than 2.7, the protein structure changes to the fully extended form. The $\alpha$-helix content decreases to a minimal value of $25 \%$, and HSA is in an expanded form and increases the exposure of its hydrophobic surface. ${ }^{25,26}$ On the other hand, an increase in $\mathrm{pH}$ to 10 also induces a reversible denaturation of HSA that exposes part of its hydrophobic residues. ${ }^{28,29}$ We hypothesized that these reversible partially denaturated structures could contribute to the binding of a highly hydrophobic molecule such as paclitaxel, leading to the formation of soluble complexes. As shown in Table 1, not only does paclitaxel form clearer solutions when incubated with denatured acid than with native HSA, but also a proportion of the complexes thus formed remains soluble even after $\mathrm{pH}$ is reversed to 7 . The differences between the preparations are also reflected in the dramatic differences in their turbidity which, when measured before clarification by centrifugation, turned out to be a good predictor of the outcome in terms of paclitaxel solubilization

Table I Effect of $\mathrm{pH}$ on the turbidity and solubility of Ptx-HSA complexes

\begin{tabular}{|c|c|c|c|c|c|c|}
\hline \multirow{2}{*}{$\begin{array}{l}\text { Ptx: HSA } \\
\text { Molar } \\
\text { ratio }\end{array}$} & \multicolumn{2}{|c|}{$\begin{array}{l}\text { Sample incubated at pH } 2.7 \\
(\mathrm{I} \text { h) adjusted } \mathrm{pH} \text { to } 7.0\end{array}$} & \multicolumn{2}{|c|}{$\begin{array}{l}\text { Sample incubated at } \\
\mathrm{pH} 7.0(\mathrm{I} \mathrm{h})\end{array}$} & \multicolumn{2}{|c|}{$\begin{array}{l}\text { Sample incubated at } \mathrm{pH} 10.0 \\
(\mathrm{I} \text { h) adjusted } \mathrm{pH} \text { to } 7.0\end{array}$} \\
\hline & $\begin{array}{l}\text { Pre-centrif. OD } \\
(600 \mathrm{~nm})\end{array}$ & $\begin{array}{l}\text { Soluble } \\
\text { Ptx } \\
\left(\mu \mathrm{g} \cdot \mathrm{mL}^{-1}\right)\end{array}$ & $\begin{array}{l}\text { Pre-centrif. OD } \\
(600 \mathrm{~nm})\end{array}$ & $\begin{array}{l}\text { Soluble } \\
\text { Ptx } \\
\left(\mu \mathrm{g} \cdot \mathbf{m L}^{-1}\right)\end{array}$ & $\begin{array}{l}\text { Pre-centrif. OD } \\
(600 \mathrm{~nm})\end{array}$ & $\begin{array}{l}\text { Soluble } \\
\text { Ptx } \\
\left(\mu \mathrm{g} \cdot \mathrm{mL}^{-1}\right)\end{array}$ \\
\hline $9: 1$ & 0.543 & 355 & 1.824 & BDL & 0.503 & 406 \\
\hline $4: 1$ & 0.596 & 446 & 1.483 & BDL & 0.604 & 442 \\
\hline $2: 1$ & 0.664 & 455 & 1.386 & BDL & 0.694 & 434 \\
\hline
\end{tabular}

Note: *Samples of HSA were adjusted to $\mathrm{pH} 2.7,7.0$ or 10.0 and kept at $25^{\circ} \mathrm{C}$ during I hour, afterwards, 0.1 volume of $\mathrm{Ptx}$ in ethanol was added to reach a final $\mathrm{Ptx}$ concentration of I mg $\cdot \mathrm{mL}^{-1}$. The samples were incubated at $25^{\circ} \mathrm{C}$ during I hour and then the $\mathrm{pH}$ was adjusted to $7.0 \mathrm{with} 0 . \mathrm{I} \mathrm{N} \mathrm{NaOH}$ or $\mathrm{HCl}$. Finally all samples were clarified by centrifugation at $14,000 \times g$ during 10 minutes and the concentration of soluble Ptx was determined by RP-HPLC as described under materials and methods. In all cases OD at $600 \mathrm{~nm}$ after centrifugation was below 0.I. Results are the means of three different experiments performed in duplicates. RSD were all $<10 \%$. Abbreviations: BDL, below detection limit; Ptx, Paclitaxel; OD, optical density; RSD, relative standard deviation. 
Table 2 Effect of incubation temperature on the turbidity and solubility of Ptx-HSA complexes

\begin{tabular}{|c|c|c|c|c|c|c|}
\hline \multirow{3}{*}{$\begin{array}{l}\text { Ptx:HSA } \\
\text { Molar } \\
\text { ratio }\end{array}$} & \multicolumn{6}{|c|}{ Incubation temperature } \\
\hline & \multicolumn{2}{|l|}{$4^{\circ} \mathrm{C}$} & \multicolumn{2}{|l|}{$25^{\circ} \mathrm{C}$} & \multicolumn{2}{|l|}{$37^{\circ} \mathrm{C}$} \\
\hline & $\begin{array}{l}\text { Pre-centrif. OD } \\
(600 \mathrm{~nm})\end{array}$ & $\begin{array}{l}\text { Soluble Ptx } \\
\left(\mu \mathrm{g} \cdot \mathbf{m L}^{-1}\right)\end{array}$ & $\begin{array}{l}\text { Pre-centrif. OD } \\
(600 \mathrm{~nm})\end{array}$ & $\begin{array}{l}\text { Soluble Ptx } \\
\left(\mu \mathrm{g} \cdot \mathrm{mL}^{-1}\right)\end{array}$ & $\begin{array}{l}\text { Pre-centrif. OD } \\
(600 \mathrm{~nm})\end{array}$ & $\begin{array}{l}\text { Soluble Ptx } \\
\left(\mu \mathrm{g} \cdot \mathrm{mL}^{-1}\right)\end{array}$ \\
\hline $9: 1$ & 0.123 & 328 & 0.352 & 240 & 1.041 & 76 \\
\hline $4: 1$ & 0.154 & 257 & 0.386 & 213 & 0.694 & 36 \\
\hline $2: 1$ & 0.203 & 252 & 0.686 & 179 & 0.760 & $\mathrm{BDL}$ \\
\hline
\end{tabular}

Note: Samples of HSA were adjusted to $\mathrm{pH} 2.7$ and kept at 4,25 or $37^{\circ} \mathrm{C}$ during I hour, afterwards, 0.1 volume of Ptx in ethanol was added to reach a final $\mathrm{Ptx}$ concentration of $0.5 \mathrm{mg} \cdot \mathrm{mL}^{-1}$. The samples were incubated at 4,25 or $37^{\circ} \mathrm{C}$ during I hour and then the $\mathrm{pH}$ was adjusted to $7.0 \mathrm{with} 0.1 \mathrm{~N} \mathrm{NaOH}$. Finally, all samples were clarified by centrifugation at $14,000 \times \mathrm{g}$ during 10 minutes and the concentration of soluble Ptx was determined by RP-HPLC as described under materials and methods. Results are the means of three different experiments performed in duplicates. RSD were all $<10 \%$.

Abbreviations: Ptx, Paclitaxel; OD, ; RSD,

(Table 1). It is important to stress the fact that all samples were optically clear (OD at $600 \mathrm{~nm}<0.1)$ after centrifugation. Similar results were obtained when defatted or excipient-free HSA was used, suggesting that neither fatty acids nor sodium caprylate or N-acetyl tryptophan interfere with binding of paclitaxel to HSA (data not shown). Incubation at an alkaline $\mathrm{pH}$ also rendered optically clear solutions of paclitaxel and HSA (Table 1).

\section{Effect of incubation temperature on binding paclitaxel to HSA}

In an attempt to optimize the binding of paclitaxel to partially unfolded albumin, we evaluated the effect of incubation temperature on the formation of water-soluble paclitaxel-HSA complexes with different molar ratios exposing hydrophobic surfaces of HSA by acid $\mathrm{pH}$. As expected, a lowered incubation temperature rendered the system more hydrophobic, and led to clearer solutions and an increased amount of paclitaxel remaining solution (Table 2).

It was also observed that the mixtures prepared at a low incubation temperature remained clearer and more soluble for at least a week at $4^{\circ} \mathrm{C}$, indicating that the complexes formed had greater stability (data not shown). Upon increasing the temperature from $4^{\circ} \mathrm{C}$ to $37^{\circ} \mathrm{C}$, unacceptable formulation mixtures were obtained due to increased precipitation of paclitaxel and HSA. Similar results were obtained at alkaline $\mathrm{pH}$, except that at a $\mathrm{pH}$ of 10 , the ester bond in paclitaxel was rapidly hydrolyzed at high temperatures (data not shown).

\section{Effect of ionic strength on formation of water- soluble paclitaxel-HSA complexes}

Given the zwitterionic character of HSA and the hydrophobicity of paclitaxel, the ionic strength of the aqueous media is almost certainly a variable that will affect the formation of water-soluble complexes between paclitaxel and HSA. First, an increase in ionic strength could reinforce and stabilize the mainly hydrophobic interaction of paclitaxel with HSA. On the other hand, using a high protein concentration, increasing ionic strength could promote interaction among albumin molecules, leading to a decrease in stability with a concomitant increase in turbidity of the solution. Although not statistically significant, a slight improvement in paclitaxel solubility was apparent with the addition of $\mathrm{NaCl}$ up to $0.4 \mathrm{M}$, suggesting that the addition of salt reinforces and stabilizes the interaction of paclitaxel with HSA (Table 3).

Table 3 Effect of ionic strength on the optical clarity and solubility of Ptx-HSA complexes

\begin{tabular}{|c|c|c|c|c|c|c|}
\hline \multirow[t]{2}{*}{$\mathrm{NaCl}(\mathrm{M})$} & \multicolumn{3}{|c|}{ Sample incubated at pH2.7* } & \multicolumn{3}{|c|}{ Sample incubated at $\mathrm{pH} 2.7(\mathrm{I} \mathrm{h})$ adjusted $\mathrm{pH}$ to $7.0 * *$} \\
\hline & $\begin{array}{l}\text { Pre-centrif. OD } \\
(600 \mathrm{~nm})\end{array}$ & $\begin{array}{l}\text { Soluble Ptx } \\
\left(\mu \mathrm{g} \cdot \mathrm{mL}^{-1}\right)\end{array}$ & $\begin{array}{l}\text { Bound } \\
\text { Ptx (\%) }\end{array}$ & $\begin{array}{l}\text { Pre-centrif. OD } \\
(600 \mathrm{~nm})\end{array}$ & $\begin{array}{l}\text { Soluble Ptx } \\
\left(\mu \mathrm{g} \cdot \mathrm{mL}^{-1}\right)\end{array}$ & $\begin{array}{l}\text { Bound } \\
\text { Ptx (\%) }\end{array}$ \\
\hline 0 & 0.266 & BDL & BDL & 0.375 & 815 & 81.5 \\
\hline 0.2 & 0.196 & 869 & 86.9 & 0.295 & 832 & 83.2 \\
\hline 0.4 & 0.196 & 890 & 89.0 & 0.298 & 910 & 91.0 \\
\hline 0.6 & 0.223 & 891 & 89.1 & 0.310 & 880 & 88.0 \\
\hline 0.8 & 0.425 & 465 & 46.5 & 0.460 & 795 & 79.5 \\
\hline I:0 & $\begin{array}{l}>2 \\
\text { (Precipitated) }\end{array}$ & $\mathrm{BDL}$ & $\mathrm{BDL}$ & $\begin{array}{l}>2 \\
\text { (Precipitated) }\end{array}$ & $\mathrm{BDL}$ & $\mathrm{BDL}$ \\
\hline
\end{tabular}

Note: *Samples of HSA $\left(20 \mathrm{mg} \cdot \mathrm{mL}^{-1}\right)$ were adjusted to $\mathrm{pH} 2.7$ and kept at $4{ }^{\circ} \mathrm{C}$ during I hour, afterwards, 0.1 volume of Ptx in ethanol was added to reach a final Ptx concentration of I mg $\cdot \mathrm{mL}^{-1}$. The samples were incubated at $4^{\circ} \mathrm{C}$ during I hour and then samples labeled ** were adjusted to $\mathrm{pH} 7.0 \mathrm{with} 0 . \mathrm{I} \mathrm{N} \mathrm{NaOH}$. All samples were incubated $\mathrm{I} h$ at $4^{\circ} \mathrm{C}$, clarified by centrifugation at $14,000 \times \mathrm{g}$ during 10 minutes and the concentration of soluble Ptx was determined by RP-HPLC as described under materials and methods. Results are the means of three different experiments performed in duplicates. RSD were all $<10 \%$.

Abbreviations: BDL, below detection limit; RSD, relative standard deviation; Ptx, Paclitaxel; OD, optical density. 


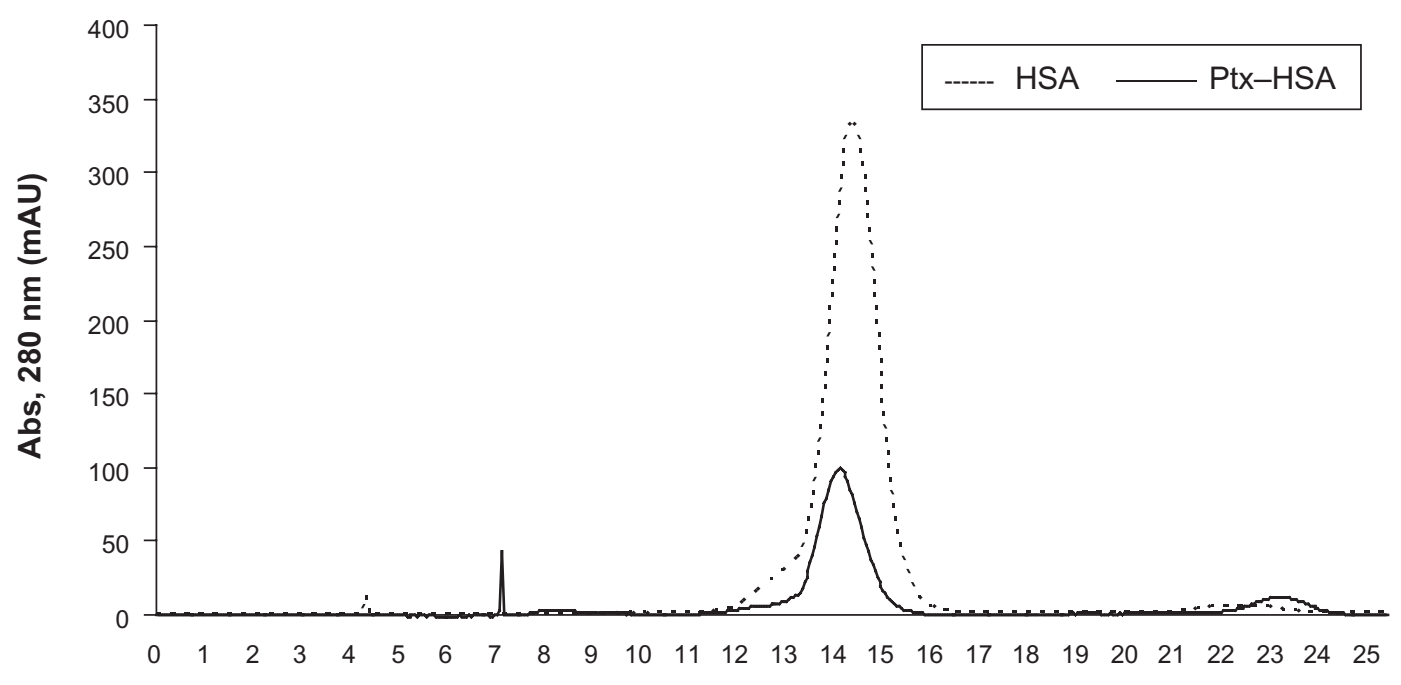

Elution volume $(\mathrm{mL})$

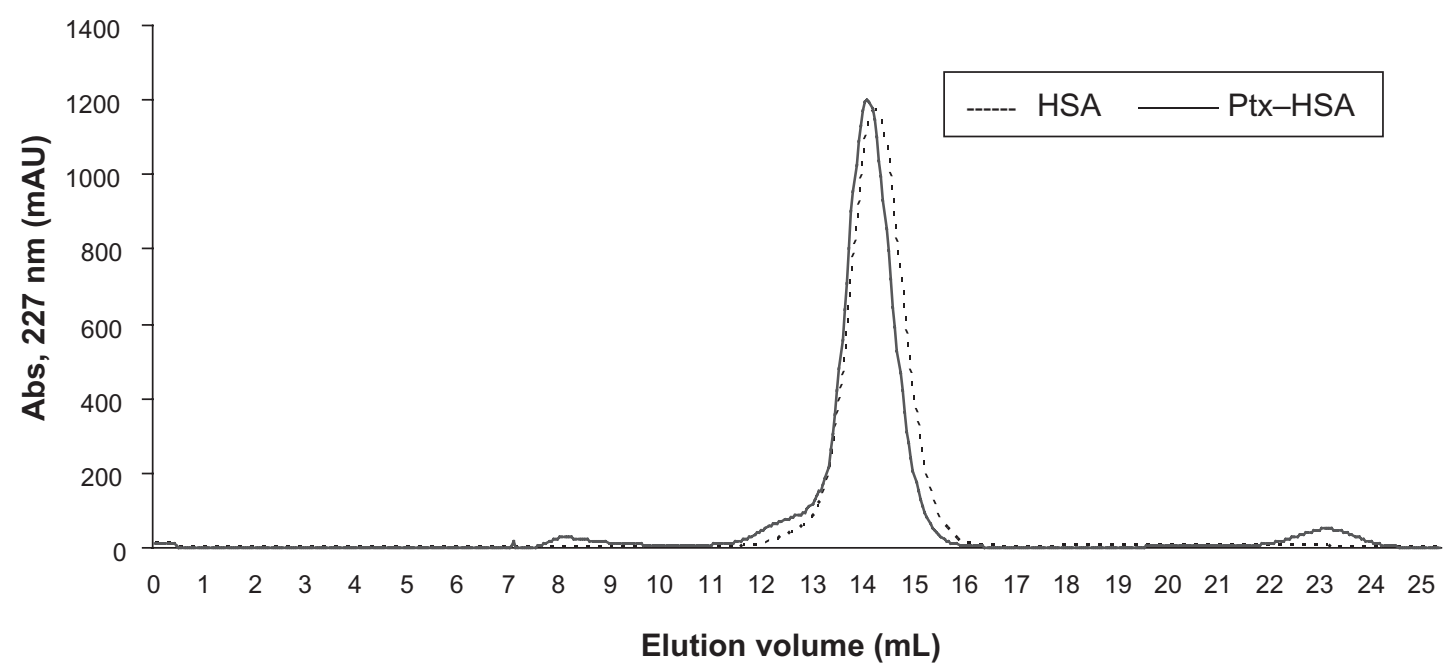

Figure I Size exclusion chromatography of HSA and paclitaxel-HSA. Chromatography on Superdex $200^{\circledR}$ of HSA (-----) and HSA-paclitaxel. Samples of HSA $5 \mathrm{mg}$ ( $10 \mathrm{mg} / \mathrm{mL}$ ) and HSA-paclitaxel $2 \mathrm{mg}\left(10 \mathrm{mg} / \mathrm{mL}\right.$ HSA and I.II mg/mL paclitaxel) were run on a Superdex $20{ }^{\circledast}$ column (HR I0/30) at room temperature in phosphate-buffered saline as described in the Materials and methods section.

Abbreviations: HSA, human serum albumin; Ptx, Paclitaxel.

As expected, we found that a gel was formed at a high ionic strength and an acidic $\mathrm{pH}$, and this led to marked precipitation of protein and turbid mixtures (Table 3). This effect was even more sensitive to salt concentration when the HSA concentration was $40 \mathrm{mg} / \mathrm{mL}$, at which a gel was formed

Table 4 Binding of Ptx-HSA to anion exchange resin

\begin{tabular}{llllll}
\hline $\begin{array}{l}\text { Paclitaxel: } \\
\text { HSA Molar }\end{array}$ & \multicolumn{2}{l}{ Nonbound to Mono Q } & & \multicolumn{2}{l}{ Eluted from Mono Q } \\
ratio & HSA (\%) & Paclitaxel (\%) & & HSA (\%) & Paclitaxel (\%) \\
\hline $9: 1$ & 5.0 & 22 & 95 & 80 \\
$4: 1$ & 8.0 & 14 & 92 & 82 \\
2:1 & 7.0 & 16 & 93 & 85 \\
\hline
\end{tabular}

Note: Results are the means of three different experiments performed in duplicate. RSD were all $<10 \%$.

Abbreviations: RSD, relative standard deviation; Ptx, Paclitaxel. with $0.6 \mathrm{M} \mathrm{NaCl}$, whereas at $60 \mathrm{mg} / \mathrm{mL}$ a gel was formed with $0.4 \mathrm{M} \mathrm{NaCl}$.

\section{Chromatography of paclitaxel-HSA complexes}

To explore the structural properties of the complexes formed between paclitaxel and acid-denatured HSA, samples of the soluble complexes formed were run on size exclusion and ionic exchange chromatography columns. As determined by reverse-phase high-pressure liquid chromatography analysis of the fractions, paclitaxel coeluted with HSA from a size exclusion resin indicating that there is a physical association between them (data not shown). It was also observed that the elution volume of HSA changed slightly upon binding of paclitaxel, suggesting that it remains monomeric and 


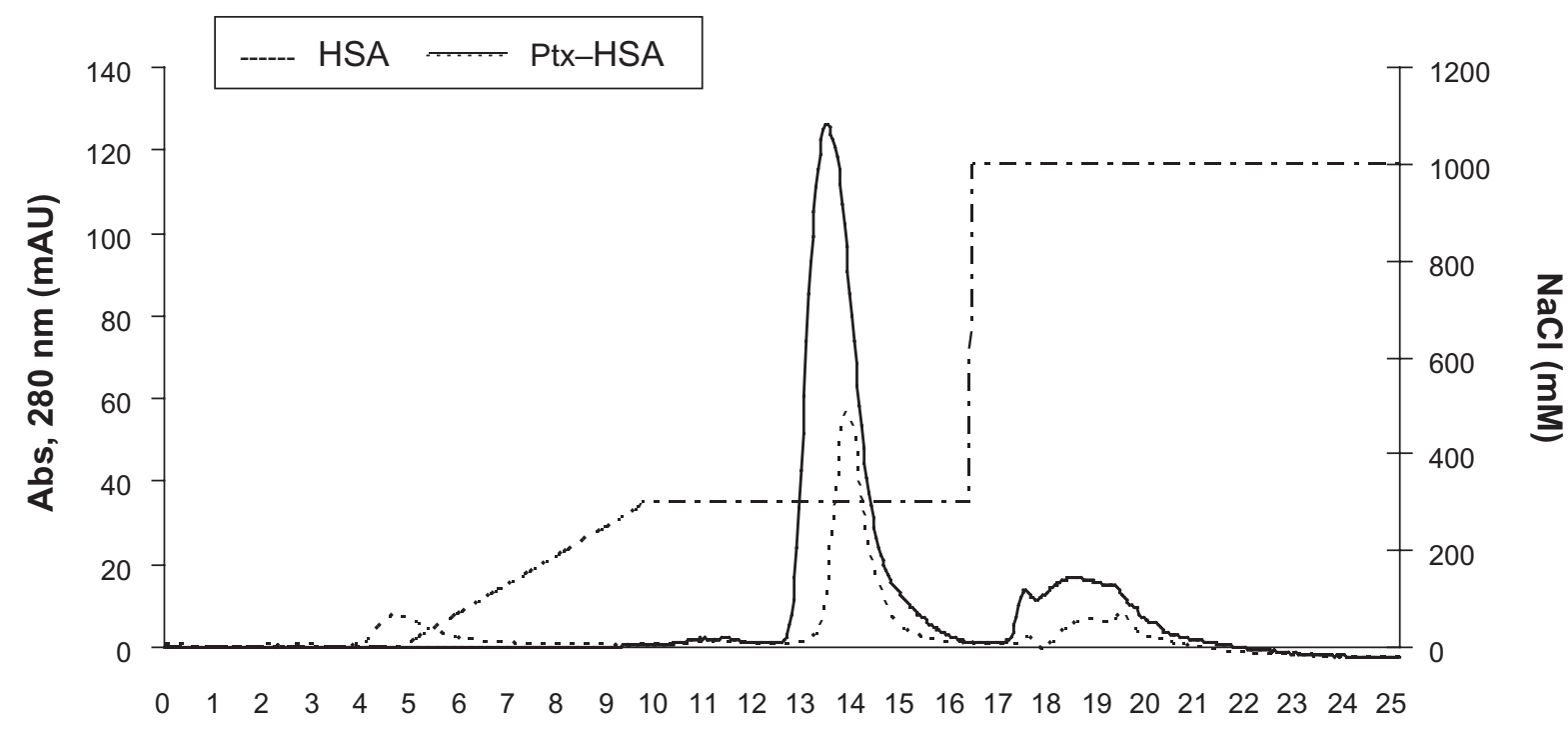

Elution volume $(\mathrm{mL})$

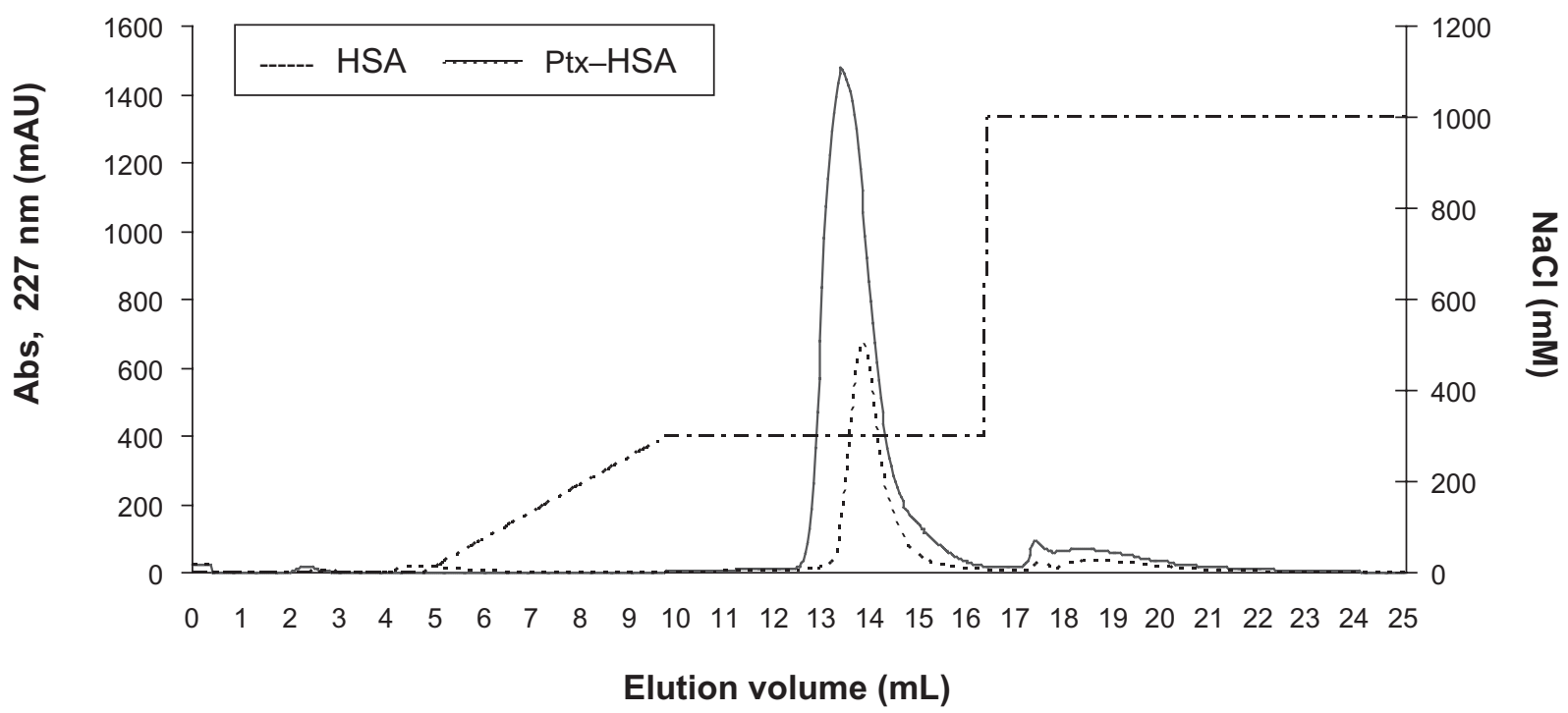

Figure 2 lonic exchange chromatography of HSA and paclitaxel-HSA complexes. Chromatography on Mono Q ${ }^{\circledR}$ of HSA (-----) and HSA-paclitaxel. Samples of 0.5 mg HSA ( $(\mathrm{mg} / \mathrm{mL})$ and $1.25 \mathrm{mg} \mathrm{HSA}$-paclitaxel $\left(5 \mathrm{mg} / \mathrm{mL} \mathrm{HSA}\right.$ and $0.214 \mathrm{mg} / \mathrm{mL}$ paclitaxel) were bound to a Mono $\mathrm{Q}^{\circledR}$ column (HR $\left.5 / 5\right)$ at room temperature in $50 \mathrm{mM}$ sodium phosphate $(\mathrm{pH} 7.0)$ and eluted with $0.3 \mathrm{M} \mathrm{NaCl}$ in $50 \mathrm{mM}$ sodium phosphate $(\mathrm{pH} 7.0)$.

Abbreviation: HSA, human serum albumin.

globular, with a hydrodynamic radius in agreement with that expected for HSA complexed with 4-6 molecules of paclitaxel (Figure 1). In agreement with this finding, more than $90 \%$ of the albumin and paclitaxel were bound and coeluted from an ionic exchange resin, with a profile similar to that of pure HSA (Table 4 and Figure 2). Altogether, these results confirm that paclitaxel is solubilized in water through a physical interaction with HSA, and also provide evidence suggesting that the complexes formed do not substantially modify the hydrodynamic radius or the net charge of HSA.

\section{Evaluation of biological activity of water-soluble paclitaxel-HSA complexes}

The test used to evaluate the biological activity of the paclitaxel-albumin complex was the inhibition of division of a tumoral cell line. As seen in Figure 3, control samples show a clear monolayer of human larynx epithelioma cells covering the surface of the Petri dishes. On the other hand, cell samples treated with paclitaxel either in Cremophor or complexed with HSA show few cells, indicating that albumin does not impair the biological effect of paclitaxel on cell division. Furthermore, at least at the dose tested, there was 

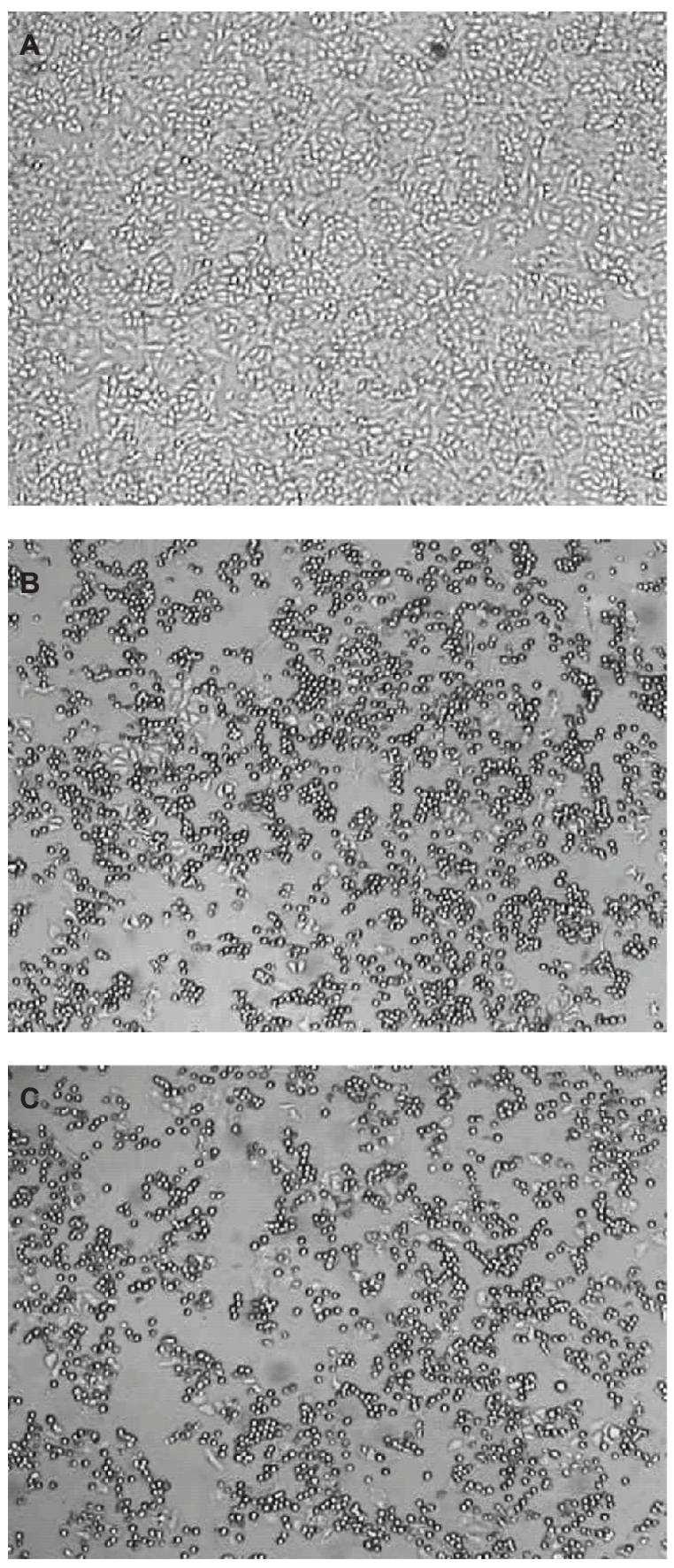

Figure 3 Effect of paclitaxel in HSA or Cremophor ${ }^{\circledR}$ on Hep-2 cells. Monolayers of Hep-2 cells without paclitaxel A), with $10 \mu \mathrm{g} / \mathrm{mL}$ paclitaxel solubilized in Cremophor ${ }^{\circledR}$ B) or complexed with HSA C).

Abbreviations: Hep-2, human larynx epithelioma; HSA, human serum albumin.

no statistical difference in the number of viable cells between paclitaxel in Cremophor and those complexed with HSA.

\section{Conclusion}

Standard formulations of taxanes require use of solvents, such as Cremophor or Tween, which contribute to some of the toxicities associated with paclitaxel-based therapy. To overcome these drawbacks, nanoparticle HSA-bound paclitaxel has been recently approved and is available commercially as Abraxane ${ }^{\circledR}$. However, this formulation is prepared by highpressure homogenization of albumin and paclitaxel, leading to the formation of a colloidal suspension with very limited stability. We hypothesized that the exposure of hydrophobic domains of albumin via a partial opening of its structure could improve its interaction with a hydrophobic molecule like paclitaxel. The results obtained confirm that, as previously known, the binding affinity of paclitaxel with native HSA is very low (Table 1) ${ }^{15}$ In agreement with our hypothesis, we found that paclitaxel readily binds to $\mathrm{pH}$-induced partially unfolded HSA, leading to the formation of optically clear water-soluble complexes. The complexes thus formed appear to be more stable in solution when the native state of HSA is at least partially restored by neutralization of the solution to a $\mathrm{pH}$ around 7. In agreement with this, we observed that the hydrodynamic radius of HSA is only slightly affected after the cycle of $\mathrm{pH}$ changes, and is consistent with paclitaxel binding. Furthermore, paclitaxel binding does not affect the overall exposure of charged groups of HSA, as evaluated by its interaction with an ionic exchange resin. The in vitro biological activity of the complexes formed was qualitatively equivalent to that of a Cremophor-based formulation.

In conclusion, our results not only show that HSA-paclitaxel complexes can be prepared by a simple method that does not require use of high-pressure homogenization, but also open up the possibility to extend this strategy for the design of novel protein-based nanodelivery vehicles for other hydrophobic active pharmaceutical ingredients. Further work is in progress in order to characterize the structure, as well as energetic and dynamic parameters of the complexes formed by the binding of paclitaxel to partially unfolded HSA and to evaluate their activity.

\section{Acknowledgments}

This work was supported by a grant from Consejo Nacional de Investigaciones Científicas y Tecnológicas (CONICET) and PICT 00696 from FONCYT. IDB and DMB are research staff and VL is a fellow of CONICET.

\section{Disclosure}

The authors report no conflicts of interest in this work.

\section{References}

1. Donehower RC, Rowinsky EK, Grochow LB, Longnecker SM, Ettinger DS. Phase I trial of Taxol in patients with advanced cancer. Cancer Treat Rep. 1987;71:1171-1177.

2. Arbuck SG, Canetta R, Onetto N, Christian M. Current dosage and schedule issues in the development of paclitaxel (Taxol). Semin Oncol. 1993;20:31-39. 
3. Weiss RB, Donehower RC, Wiernik PH, et al. Hypersensitivity reactions from Taxol. J Clin Oncol. 1990;8:2325-2327.

4. Friedland D, Gorman G, Treat J. Hypersensitivity reactions from taxol and etoposide. J Natl Cancer Inst. 1992;85:2036.

5. Szebeni J, Muggia FM, Alving CR. Complement activation by Cremophor EL as a possible contributor to hypersensitivity to paclitaxel: An in vitro study. J Natl Cancer Inst. 1998;90:300-306.

6. Sharma A, Straubinger RM. Novel taxol formulations: Preparation and characterization of taxol-containing liposomes. Pharm Res. 1994;11: 889-896.

7. Sharma US, Balasubramanian SV, Straubinger RM. Pharmaceutical and physical properties of paclitaxel $\left(\mathrm{Taxol}^{\circledR}\right)$ complexes with cyclodextrins. J Pharm Sci. 1995;84:1223-1230.

8. Alkan-Onyuksel H, Ramakrishnan S, Chai HB, Pezzuto JM. A mixed micellar formulation suitable for the parenteral administration of taxol. Pharm Res. 1994;11:206-212.

9. Lee HJ, Lee KR, Park TG. Hyaluronic acid-paclitaxel conjugate micelles: Synthesis, characterization, and antitumor activity. Bioconjug Chem. 2008;19:1319-1325.

10. Singer JW, Shaffer S, Baker B, et al. Paclitaxel poliglumex (XYOTAX; CT-2103): An intracellularly targeted taxane. Anticancer Drugs. 2005; 16:243-254

11. Fasano M, Curry S, Terreno E, et al. The extraordinary ligand binding properties of human serum albumin. IUBM Life. 2005;57:787-796.

12. Hawkins MJ, Soon-Shiong P, Desai N. Protein nanoparticles as drug carriers in clinical medicine. Adv Drug Deliv Rev. 2008;60:876-885.

13. Miele E, Spinelli GP, Miele E, Tomao F, Tomao S. Albumin-bound formulation of paclitaxel (Abraxane ABI-007) in the treatment of breast cancer. Int J Nanomedicine. 2009;4:99-105.

14. Sebak S, Mirzaei M, Malhotra M, Kulamarva A, Prakash S. Human serum albumin nanoparticles as an efficient noscapine drug delivery system for potencial use in breast cancer: Preparation and in vitro analysis. Int J Nanomedicine. 2010;5:525-532.

15. Desai NP, Soon-Shiong P, Sandford PA, Grinstaff MW, Suslick KS. Methods for in vivo delivery of substantially water insoluble pharmacologically active agents and compositions useful therefore. United States Patent 5, 439686. August 8, 1995.
16. Desai NP, Tao C, Yang A, et al. Protein stabilized pharmacologically active agents, methods for the preparation thereof and methods for the use thereof. United States Patent 6749868. June 15, 2004.

17. Paál K, Shkarupin A, Beckford L. Paclitaxel binding to human serum albumin - automated docking studies. Bioorg Med Chem. 2007;15: $1323-1329$.

18. Trynda-Lemiesz L. Paclitaxel-HSA interaction. Binding sites on HSA molecule. Bioorg Med Chem. 2004;12:3269-3275.

19. Bertucci C, Cimitan S, Riva A, Morazzoni P. Binding studies of taxanes to human serum albumin by bioaffinity chromatography and circular dichroism. J Pharm Biomed Anal. 2006;42:81-87.

20. Paál K, Müller J, Hegedüs L. High affinity binding of paclitaxel to human serum albumin. Eur J Biochem. 2001;268:2187-2191.

21. Kumar GN, Walle UK, Bhalla KN, Walle T. Binding of taxol to human plasma, albumin and alpha 1-acid glycoprotein. Res Commun Chem Pathol Pharmacol. 1993;80:337-344.

22. Purcell M, Neault JF, Tajmir-Riahi HA. Interaction of taxol with human serum albumin. Biochim Biophys Acta. 2000;1478:61-68.

23. Chen R. Removal of fatty acids from serum albumin by charcoal treatment. J Biol Chem. 1967;25:173-181.

24. Ausar SF, Bianco ID, Badini GD, et al. J Dairy Sci. 2001;84: 361-369.

25. Wallevik K, Hvidt A. Conformational changes in human serum albumin as revealed by hydrogen-deuterium exchange studies. J Biol Chem. 1972;247:1530-1535.

26. El Kadi N, Taulier N, Le Huérou JY, et al. Unfolding and refolding of bovine serum albumin at acid $\mathrm{pH}$ : Ultrasound and structural studies. Biophys J. 2006;91:3397-3404.

27. Muzammil S, Kumar Y, Tayyab S. Molten globule-like state of human serum albumin at low pH. Eur J Biochem. 1999;266:26-32.

28. Wallevik K. Reversible denaturation of human serum albumin by $\mathrm{pH}$, temperature, and guanidine hydrochloride followed by optical rotation. J Biol Chem. 1973;248:2650-2655.

29. Dockal M, Carter DC, Rüker F. Conformational transitions of the three recombinant domains of human serum albumin depending on $\mathrm{pH}$. J Biol Chem. 2000;275:3042-3050.
International Journal of Nanomedicine

\section{Publish your work in this journal}

The International Journal of Nanomedicine is an international, peerreviewed journal focusing on the application of nanotechnology in diagnostics, therapeutics, and drug delivery systems throughout the biomedical field. This journal is indexed on PubMed Central, MedLine, CAS, SciSearch ${ }^{\circledR}$, Current Contents ${ }^{\circledR} /$ Clinical Medicine,

\section{Dovepress}

Journal Citation Reports/Science Edition, EMBase, Scopus and the Elsevier Bibliographic databases. The manuscript management system is completely online and includes a very quick and fair peer-review system, which is all easy to use. Visit http://www.dovepress.com/ testimonials.php to read real quotes from published authors. 